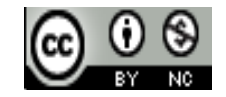

Jurnal Pendidikan Matematika Indonesia is licensed under

A Creative Commons Attribution-Non Commercial 4.0 International License

\title{
MODEL DISCOVERY LEARNING BERBANTUAN GEOGEBRA UNTUK MeningKatKan Kemampuan Pemecahan MaSalah
}

\author{
Ferdinandus Mone ${ }^{1)}$, Alfonsa Maria $\mathrm{Abi}^{2)}$ \\ 1) Program Studi Pendidikan Matematika STKIP SOE, NTT, Indonesia \\ E-mail:ferdimone@yahoo.com \\ 2) Program Studi Pendidikan Matematika STKIP SOE, NTT, Indonesia \\ 3) Program Studi Pendidikan Matematika STKIP SOE, NTT, Indonesia
}

\begin{abstract}
Abstrak. Kualitas Pendidikan di daerah tertinggal tidak dapat disamakan dengan pendidikan di daerah maju. Rendahnya kualitas pendidikan di Daerah tertinggal dapat disebabkan karena fasilitas pendidikan yang jauh lebih minim dari pada daerah maju, salah satunya adalah minimnya media pembelajaran. Rendahnya kualitas pembelajaran di sekolah menengah membuat kualitas input ke perguruan tinggi daerah setempat juga ikut rendah sehingga mahasiswa perlu mengejar keteritinggalan pengetahuan yang sudah terlewati. Peran pengajar dalam menghadapi masalah ini dapat di lakukan melalui desain model pembelajaran berbasis masalah berbantuan media software untuk mengefektifkan pembelajaran, salah satunya software geogebra. Hasil penelitian dalam menerapkan model Discovery Learning berbantuan Geogebra menunjukkan bahwa terjadi peningkatan kemampuan pemecahan masalah setelah terjadi proses pembelajaran, terjadinya ketuntasan kemampuan pemecahan masalah dan kemampuan pemecahan masalah mahasiswa yang diajarkan dengan model Discovery Learning berbantuan Geogebra lebih baik dari mahasiswa yang diajarkan dengan model konvensional.
\end{abstract}

Kata Kunci: Discovery Learning, Pemecahan Masalah, Geogebra

\section{PENDAHULUAN}

Nilai rata-rata matematika siswa kelas VIII Indonesia menempati urutan ke-38 dari 42 negara (TIMSS, 2011) sedangakan hasil PISA 2012 lalu mengeluarkan survei bahwa Indonesia menduduki peringkat paling bawah dari 65 negara (PISA, 2012). Indonesia masih jauh tertinggal oleh negaranegara lain di kancah internasional. Dari hasil survey kedua lembaga tersebut, memberikan Gambaran kemampuan matematika siswa Indonesia berada pada tingkatan kognitif mengetahui (knowing) yang merupakan tingkatan terendah menurut kriteria tingkatan kognitif dari Mullis et. al dalam Masduki (2013) siswa Indonesia belum dapat menerapkan pengetahuan dasar yang dimiliki untuk menyelesaikan masalah (applying), serta belum mampu memahami dan menerapkan pengetahuan dalam masalah yang kompleks, membuat kesimpulan, serta menyusun generalisasi (reasoning).
Selain kemampuan siswa yang rendah, kemampuan guru dalam menyampaikan materi pembelajaran juga masih rendah. Hal ini terlihat dari hasil Uji Kompetensi Guru (UKG) tahun 2015. Berdasarkan hasil UKG 2015 provinsi Nusa Tenggara Timur (NTT), rata-rata kemampuan guru pada bidang pedagogic dan bidang profesional adalah 47,07 atau masih dibawah standar minimal rata-rata kemampuan guru yang diharapkan yaitu 55. Rata-rata kemampuan guru dalam kedua ranah diatas menempatkan kemampuan guru dalam ranah pedagogic dan professional pada urutan 23 dari 34 provinsi di Indonesia (Kemdikbud, 2013). Berdasarkan hasil tersebut juga menunjukkan bahwa para guru di NTT belum memenuhi standar minimal dalam mengajar sehingga perlu ditingkatkan. Salah satu bentuk kerja sama adalah adanya bentuk kerja sama dengan perguruan tinggi setempat dalam meningkatkan kulaitas pembelajaran. 
Sekolah Tinggi Keguruan dan Ilmu Pendidikan (STKIP) Soe sebagai salah satu perguruan tinggi baru di kabupaten TTS terdiri dari 4 program studi, salah satunya adalah program studi Pendidikan Matematika. Berdasarkan data input, mahasiswa STKIP Soe program studi pendidikan matematika kebanyakan berlatar belakang SMK, SMA jurusan IPS dan Bahasa, atauupun mahasiswa yang putus kuliiah dari universitas lainnya serta ketertinggalan dalam IPTEK, dengan kata lain STKIP Soe memiliki input yang kurang baik (STKIP Soe, 2016). Input yang kurang baik membuat para pengajar harus menghadapi mahasiswa dengan penuh kesabaran dalam menanamkan setiap konsep serta perlunya strategi pembelajaran yang mampu memanfaatkan waktu yang tersedia secara efisien.

Pembelajaran kalkulus di STKIP Soe sangat membutuhkan model dan strategi pembelajaran yang mampu memngkkatifkan mahasiswa maupun meningkatkan ketrampilan Dosen dalam pembelajaran. Mata kuliah ini diambil oleh mahasiswa pendidikan matematika baik yang baru mengambilnya dan maupun yang mengulang matakuliah. Mahasiswa yang mengulang terdiri dari dua kelas sedangkan mahasiswa yang baru program terdiri dari satu kelas. Kreatifitas dosen dalam menjalankan pembelajaran demi meningkatkan pemahaman mahasiswa sangatlah memegang peran penting pada matakuliah kalkulus diferensial sebab matakuliah ini menjadi prasyarat untuk matakuliah selanjutnya.

Berdasarkan latar belakang masalah di Atas maka tujuan penelitian ini adalah: (1) Untuk mengetahui ketuntasan belajar materi kalkulus pada kelas yang diajarkan dengan model Discovery Learning berbantuan geogebra; (2) Untuk menganalisis kemampuan pemecahan masalah mahasiswa materi kalkulus yang diajarkan dengan model Discovery Learning berbantuan Geogebra apabila dibandingkan dengan kemampuan pemecahan masalah mahasiswa yang diajarkan dengan model pembelajaran konvensional.

\section{Metode Penelitian}

Jenis penelitian ini adalah penelitian kuantitatif model true-experimental yang didesain dalam bentuk pre-test and post-test control-group design
(Sugiyono, 2012). Desain penelitian disajikan pada Gambar 1.

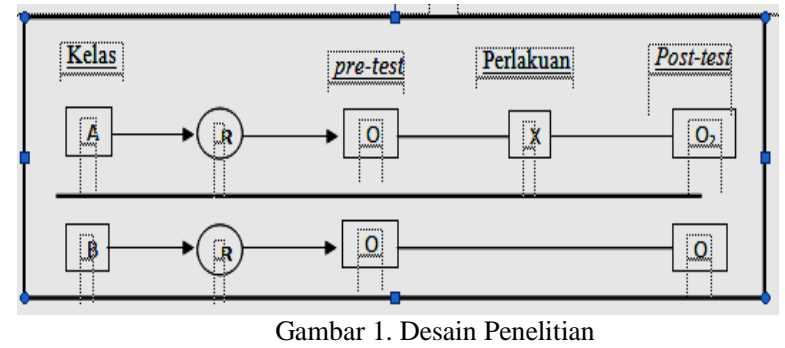

Populasi penelitian adalah mahasiswa STKIP SoE yang mengambil mata kuliah kalkulus diferensial yang terdiri dari 3 kelas dengan Teknik pengambilan sampel yang dipakai dalam penelitian ini adalah cluster random sampling. Hasil dari cluster random sampling ini adalah mahasiswa semester IV kelas A dan mahasiswa semester IV kelas B. pada penelitian ini yang menjadi kelas dengan model Discovery Learning dan kelas Mahasiswa Semester IV B sebagai kelas dengan model konvensional.

Data penelitian untuk menganalisis keefektifan model pembelajaran Discovery Learning berbantuan geogeba dalam meningkatkan kemampuan pemecahan diperoleh melalui observasi, wawancara, Tes kemampuan pemecahan masalah dan Lembar kerja mahasiswa demi. Sebelum penelitian dilakukan soal Tes Kemampuan Pemecahan Masalah (TKPM) diujicobakan terlebih dahulu. Hasil uji komudia dianalisis untuk mengetahui tingkat validitas dan reliabilitas soal tes. Banyaknya butir soal yang diujicobakan adalah 10 butir soal dan diperoleh 6 butir soal yang valid dan mencakup semua indikator dalam mengukur kemampuan pemecahan masalah Mahasiswa, selain itu keenam butir soal tersebut reliabel sehingga keenam butir soal tersebut layak dijadikan soal Tes kemampuan Pemecahan Masalah.

Pelaksanaan penelitian dimulai dari menyebarkan soal pretes untuk mengetahui kemampuan awal kedua kelas tersebut. Hasil dari pretees menunjukkan bahwa data kemampuan pemecahan masalah berdistribusi normal, rata-rata kemampuan pemecahan masalah dari kedua kelas tersebut sama, sebaran kemampuan kedua kelas tersebut sama sehingga hasil penelitian nantinya 


\section{- - - Jurnal Pendidikan Matematika Indonesia \\ Volum 2 Nomor 1 bulan Maret 2017. Page 7-12 \\ p-ISSN: 2477-5967 e-ISSN: 2477-8443}

dapat merepresentasikan populasi. Brikut ini adalah hasil uji kesamaan rata-rata dari hasil pretes.

TABEL I

Uji Homogenitas dan KesamaAn RATA-RATA PRETES KeMAMPUAN PEMECAHAN MASALAH

\begin{tabular}{|c|c|c|c|c|c|c|}
\hline & & \multicolumn{2}{|c|}{$\begin{array}{c}\text { Levene's Test } \\
\text { for Equality } \\
\text { of Variances }\end{array}$} & \multicolumn{3}{|c|}{$\begin{array}{c}\text { t-test for Equality of } \\
\text { Means }\end{array}$} \\
\hline & & $\mathbf{F}$ & Sig. & $\mathbf{t}$ & df & $\begin{array}{l}\text { Sig. (2- } \\
\text { tailed) }\end{array}$ \\
\hline \multirow[t]{2}{*}{$\begin{array}{l}\text { NILAI } \\
\text { PRET } \\
\text { ES }\end{array}$} & $\begin{array}{l}\text { Equal } \\
\text { variances } \\
\text { assumed }\end{array}$ & .004 & .950 & 1.803 & 38 & .079 \\
\hline & $\begin{array}{l}\text { Equal } \\
\text { variances not } \\
\text { assumed }\end{array}$ & & & 1.803 & 35.668 & .080 \\
\hline
\end{tabular}

Nilai singifikan uji homogenitas adalah 0,950 > 0,05 dan nilai singnifikan uji kesamaan rata-rata adalah 0,079>0,05 sehingga diperoleh sebaran data homogen dan rata-rata kemampuan pemecahan masalah sebelum diberi perlakuan sama.

\section{HASIL DAN PEMBAHASAN}

Untuk mengetahui keefektifan model pembelajaran Discovery Learning berbantuan Geogebra maka kelas A diajarkan menggunakan model pembelajaran Discovery Learning berbantuan Geogebra sedangkan kelas B dijadikan kelas kontrol yang diajarkan dengan model konvensional. Data TKPM dianalis untuk mengetahui kenormalan dari data dan diperoleh data beristribusi normal. Uji normalitas data menggunakan uji Kolmogorof Smirnov [5]. Hasil uji normalitas data ditunjukkan dalam Tabel II.

TABEL II

Uji NORMALITAS HASIL KEMAMPUAN PEMECAHAN MASAlaH

One-Sample Kolmogorov-Smirnov Test

\begin{tabular}{llr}
\hline & NILAI_POSTES \\
\hline $\mathbf{N}$ & & $\mathbf{4 0}$ \\
\hline Normal Parameters $^{\mathrm{a}}$ & Mean & 72.5500 \\
& Std. Deviation & 10.48797 \\
Most Extreme & Absolute & .141 \\
Differences & Positive & .096 \\
& Negative & -.141 \\
Kolmogorov-Smirnov Z & .893 \\
\multicolumn{2}{l}{ Asymp. Sig. (2-tailed) } & .403 \\
\hline
\end{tabular}

a. Test distribution is Normal.
One-Sample Kolmogorov-Smirnov Test

\begin{tabular}{llr}
\hline & NILAI_POSTES \\
\hline $\mathbf{N}$ & & $\mathbf{4 0}$ \\
\hline Normal Parameters $^{\mathrm{a}}$ & Mean & 72.5500 \\
& Std. Deviation & 10.48797 \\
Most Extreme & Absolute & .141 \\
Differences & Positive & .096 \\
& Negative & -.141 \\
Kolmogorov-Smirnov Z & .893 \\
Asymp. Sig. (2-tailed) & & .403 \\
\hline
\end{tabular}

Berdasarkan hasil uji pada Tabel II diperoleh nilai signifikan $0,403>0,05$ sehingga data berdistribusi normal, dengan demikian uji parametrik dipakai untuk menguji hipotesis penelitian. Berikut ini adalah rincian uji hipotesis penelitian

\section{A. Uji Ketuntasan}

Uji ketuntasan individual digunakan untuk mengetahui apakah pencapaian kemampuan pemecahan masalah mahasiswa di kelas dengan model Discovery Learning berbantuan geogebra telah mencapai minimal 70. Analisis uji ketuntasan menggunakan one sample $\mathrm{t}$ test (Sukestiyarno, 2013).

Berdasarkan data yang diperoleh, hasil analisis dari uji ketuntasan tampak seperti pada Tabel III.

Hasil Uji Ketuntasan Tes Kemampuan Pemecahan Masalah

\begin{tabular}{lrrrr}
\hline \multicolumn{4}{c}{ One-Sample Test } \\
& \multicolumn{4}{c}{ Test Value $=70$} \\
& $\mathbf{T}$ & & df & Sig. (2-tailed) \\
\hline POST_EKS & 2.125 & 19 & .047 \\
\hline
\end{tabular}

Uji ketuntansan menggunakan uji one sample $t$ test menunjukkan bahwa nilai $\mathrm{t}$ hitung $=2.125>\mathrm{t}$ tabel $=1,729$ sehingga diperoleh kesimpulan kemampuan pemecahan masalah mahasiswa yang diajarkan dengan model Discovery Learning berbantuan geogebra tuntas secara signifikan. Ketuntasan kemampuan pemecahan masalah didukung oleh pembelajaran yang efisien serta penggunaan media pembelajaran Geogebra dalam memhami setiap konsep yang diberikan. Salah satu contoh hasil karya mahasiswa dalam membuktikan konsep limit menggunakan geogebra tampak seperti gambar di bawah ini. 


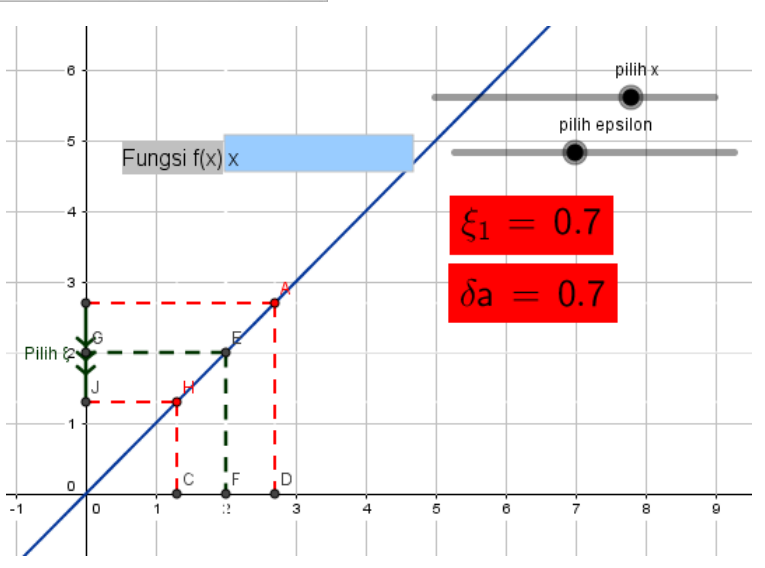

TABEL IV

HASIL Uji BANDING KeMAMPUAN PEMECAHAN MASALAH

\begin{tabular}{|c|c|}
\hline -II E & -11 \\
\hline$\xi_{1}$ & ба \\
\hline 0.45 & 0.45 \\
\hline 0.35 & 0.35 \\
\hline 0.3 & 0.3 \\
\hline 0.25 & 0.25 \\
\hline 0.2 & 0.2 \\
\hline 0.15 & 0.15 \\
\hline 0.1 & 0.1 \\
\hline 0.05 & 0.05 \\
\hline 0 & 0 \\
\hline 0.05 & 0.05 \\
\hline 0.1 & 0.1 \\
\hline 0.15 & 0.15 \\
\hline 0.2 & 0.2 \\
\hline 0.25 & 0.25 \\
\hline 0.3 & 0.3 \\
\hline 0.35 & 0.35 \\
\hline 0.4 & 0.4 \\
\hline 0.45 & 0.45 \\
\hline 0.5 & 0.5 \\
\hline
\end{tabular}

Gambar 2. Pembuktian Konsep Limit Menggunakan Geogebra

Mahasiswa dengan penuh semangat mempresentasikan hasil mereka dengan mengatakan berdasarkan tabel hasil animasi nilai $\varepsilon_{1}$ (memilih sembarang nilai $\varepsilon_{1}$ ) diperoleh nilai dengan demikian terbukti bahwa $\lim _{x \rightarrow 2}(x)=2$.

\section{B. Uji Banding}

Uji banding digunakan untuk membandingkan rataan suatu variabel antara data kelas dengan model Discovery learning dan data dari kelas dengan model konvensional. Hasil dari uji banding tampak seperti Tabel IV berikut.

\begin{tabular}{|c|c|c|c|c|c|c|}
\hline \multicolumn{7}{|c|}{ Independent Samples Test } \\
\hline & & \multicolumn{2}{|c|}{$\begin{array}{c}\text { Levene's } \\
\text { Test for } \\
\text { Equality } \\
\text { of } \\
\text { Variance } \\
\text { s } \\
\end{array}$} & \multicolumn{3}{|c|}{$\begin{array}{l}\text { t-test for Equality } \\
\text { of Means }\end{array}$} \\
\hline & & & Sig & & & $\begin{array}{c}\text { Sig. } \\
(2- \\
\text { taile }\end{array}$ \\
\hline & & $\mathbf{F}$ &. & $\mathbf{t}$ & df & d) \\
\hline \multirow{2}{*}{$\begin{array}{l}\text { NILAI } \\
\text { POS } \\
\text { TES }\end{array}$} & $\begin{array}{l}\text { Equal variances } \\
\text { assumed }\end{array}$ & $\begin{array}{r}2.55 \\
3\end{array}$ & $\begin{array}{r}.11 \\
8\end{array}$ & $\begin{array}{r}2.35 \\
8\end{array}$ & 38 & .024 \\
\hline & $\begin{array}{l}\text { Equal variances } \\
\text { not assumed }\end{array}$ & & & $\begin{array}{r}2.35 \\
8\end{array}$ & $\begin{array}{r}24.18 \\
0\end{array}$ & .027 \\
\hline
\end{tabular}

Berdasarkan data pada Tabel IV diperoleh nilai $\mathrm{t}$ hitung $=2,358$. Nilai $\mathrm{t}$ hitung dibandingkan dengan nilai $t$ tabel dengan $=5 \%$ dengan derajat kebebasan $\mathrm{n} 1+\mathrm{n} 2-2$ dan diperoleh hasil dari $\mathrm{t}$ tabel $(38 ; 0,05)=1,681$. Nilai $\mathrm{t}$ hitung $>\mathrm{t}$ tabel sehingga diperoleh kesimpulan rata-rata kemampuan pemecahan masalah mahasiswa yang diajarkan dengan model Discovery Learning berbantuan geogebra lebih baik dari mahasiswa yang diajarkan dengan model konvensional.

\section{Contoh masalah:}

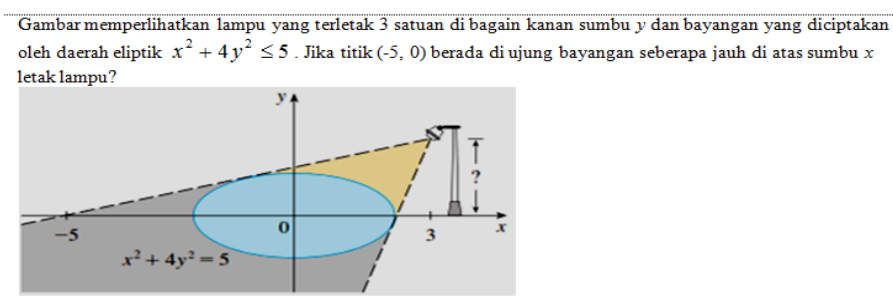

Gambar 3. Ilustrasi Soal

Jawaban Mahasiswa:

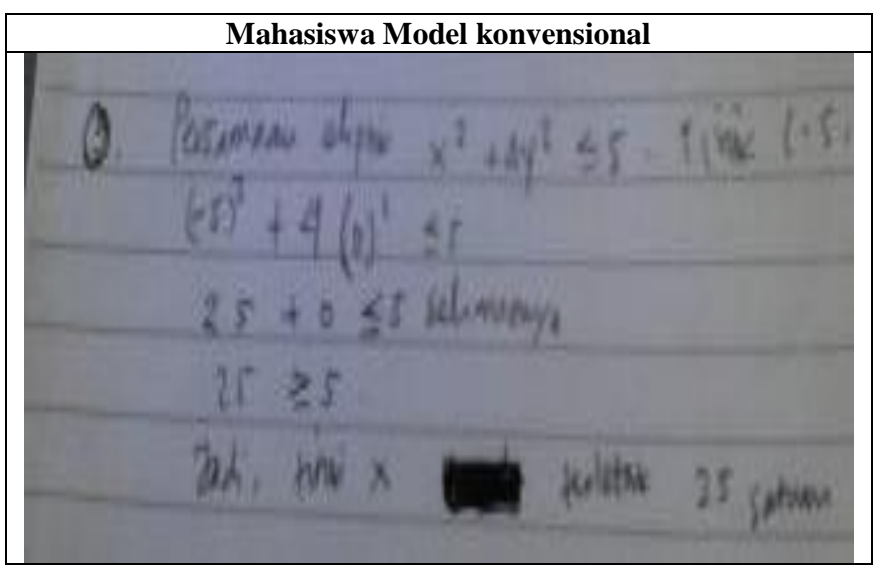




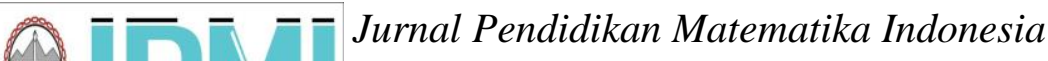 \\ Volum 2 Nomor 1 bulan Maret 2017. Page 7-12 \\ p-ISSN: 2477-5967 e-ISSN: 2477-8443}

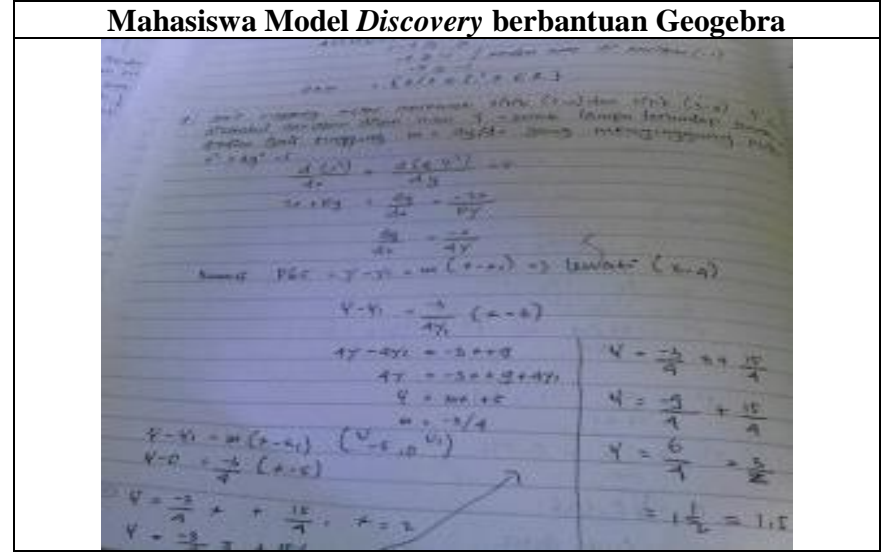

Gambar 4. Jawaban Mahasiswa

Hasil analisis yang menunjukkan bahwa ratarata kemampuan pemecahan masalah mahasiswa yang diajarkan dengan model Discovery Learning berbantuan geogebra lebih baik dari model konvensional disebebkan karena mahasiswa yang diajarkan dengan model Discovery Learning lebih terbiasa menyelesaiakan masalah dan dapat memilih berbagai strategi penyelesaian masalah termasuk penggunaan geogebra sebagai alat bantu merancang strategi penyelesaian masalah. Kreatifitas dan keaktifan mahasiswa pada model Discovery Learning berbantuan geogebra juga lebih baik dari model konvensional, hal ini terlihat dari hasil kerja kelompok dengan presentasi hasil yang maksimal. Peningkatan kretifitas mahasiswa yang terjadi dalam penelitian ini sejalan dengan penelitian yang dilakukan oleh Aryuni pada Kelas XII IPA SMA Negeri Se-Kabupaten Kudus Tahun Pelajaran 2013/2014 (Aryuni, 2014).

\section{Uji Peningkatan}

Uji peningkatan digunakan untuk mengetahui peningkatan kemampuan pemecahan masalah terhadap mahasiswa yang diajarkan dengan model Discovery Learning berbantuan geogebra. Analisis statistik yang digunakan adalah paired sample $t$ tes [5]. Hasil analis uji $t$ dua sampel berpasangan tampak pada tabel $\mathrm{V}$.

TABEL V

Uji PENINGKATAN KEMAMPUAN PEMECAHAN MASALAH

\begin{tabular}{llllr}
\hline \multicolumn{5}{c}{ Paired Samples Test } \\
\hline & t & df & $\begin{array}{l}\text { Sig. (2- } \\
\text { tailed) }\end{array}$ \\
\hline Pair 1 & $\begin{array}{l}\text { NILAI_POSTES - } \\
\text { NILAI_PRETES }\end{array}$ & 14.581 & 39 & .000 \\
\hline
\end{tabular}

Berdasarkan Tabel $\mathrm{V}$, diperoleh nilai signifikan $0,00<0,05$ sehingga diperoleh kesimpulan bahwa terdapat peningkatan kemampuan pemecahan masalah setelah diajarkan dengan model Discovery Learning berbantuan geogebra. Berikut ini adalah gratik yang menunjukkan terjadinya peningkatan kemampuan pemecahan masalah setelah diajarkan dengan model Discovery Learning berbantuan geogebra. Hasil peningkatan kemampuan pemecahan masalah dideskripsikan pada diagram garis berikut.

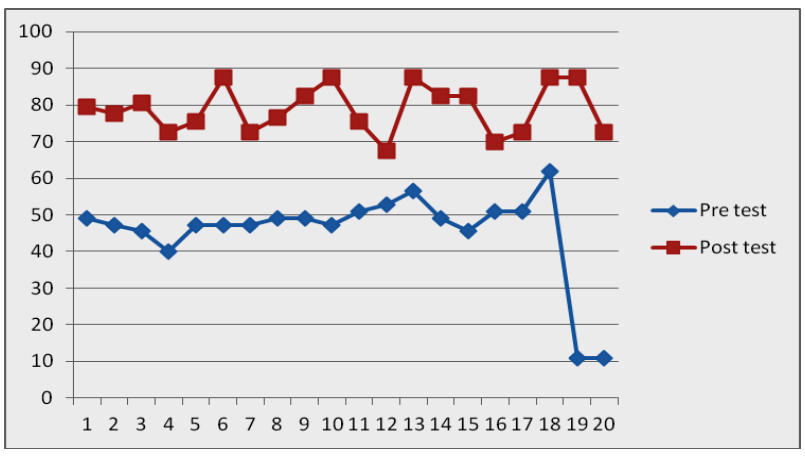

Gambar 5. Diagram Peningkatan Kemampuan Pemecahan Masalah

\section{KESIMPULAN DAN SARAN}

Berdasarkan hasil pembahasan maka penelitian ini mempunyai kesimpulan bahwa model Discovery Learning berbantuan geogebra efektif untuk meningkatkan kemampuan pemecahan masalah mahasiswa STKIP Soe, hal ini terlihat dari (a) kemampuan pemecahan masalah mencapai; (b) kemampuan pemecahan masalah siswa kelas yang diajarkan dengan model Discovery Learning berbantuan geogebra lebih baik daripada siswa yang diajarkan dengan model konvensional; (c) terjadi peningkatan peningkatan kemampuan pemecahan masalah setelah diajarkan dengan model Discovery Learning berbantuan geogebra pada materi kalkulus.

Berdasarkan hasil teori dan pengalaman dalam melaksanakan penelitian maka saran peneliti adalah perlunya strategi yang tepat dalam mengefektifkan pembelajaran dan mengefisiensi waktu baik dari metode, strategi maupun media lain yang dapat diinovasi sesuai dengan kebutuhan, terutama dalam memahami konsep dan menyelesaikan masalah. 


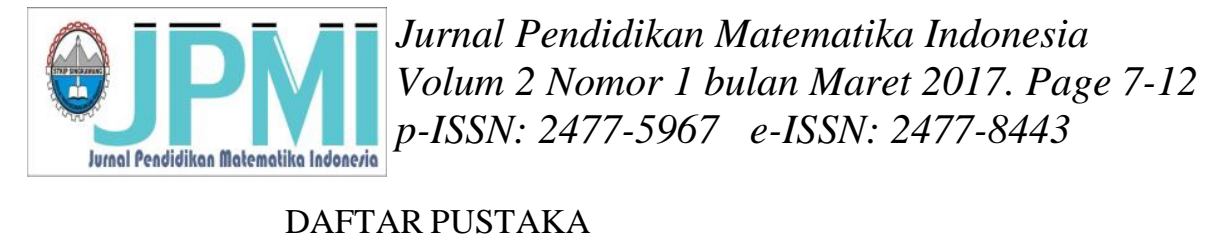

Aryuni Puji. (2014). "Eksperimentasi Model Pembelajaran Kooperatif Tipe Teams Games Tournament Dan Student Teams Achievement Division Berbantuan Media Geogebra Pada Materi Program Linear Ditinjau Dari Kreativitas Belajar Siswa Kelas Xii Ipa Sma Negeri Se-Kabupaten Kudus Tahun Pelajaran 2013/2014”. Jurnal Elektronik Pembelajaran Matematika, 2 (3): 270 - 280.

Kemdikbud. (2013). Daftar peringkat UKG 2015. Jakarta.

Masduki. (2013). Level Kognitif Soal-Soal Buku Pelajaranmatematika SMP Penguatan Peran Matematika dan Pendidikan Matematika untuk Indonesia yang Lebih Baik: 421-428. Yogyakarta: FMIPA UNY.

PISA. (2012). What Students Know and Can Do: Student Performance in Mathematics, Reading and Science, Summarises the Performance of Students in PISA 2012, 1:5-6. OECD: http://www.oecd.org/pisa/keyfindings/pisa-2012-results-volume-i.htm. (diunduh tanggal 4 Agustus 2014).

Sugiyono. (2012) .Metode Penelitian Pendidikan Pendekatan Kuantitatif, Kualitatif, dan R \& D. Bandung: Alfabeta.

Sukestiyarno. (2013). Olah Data Penelitan berbantuan SPSS. Semarang UNNES. 